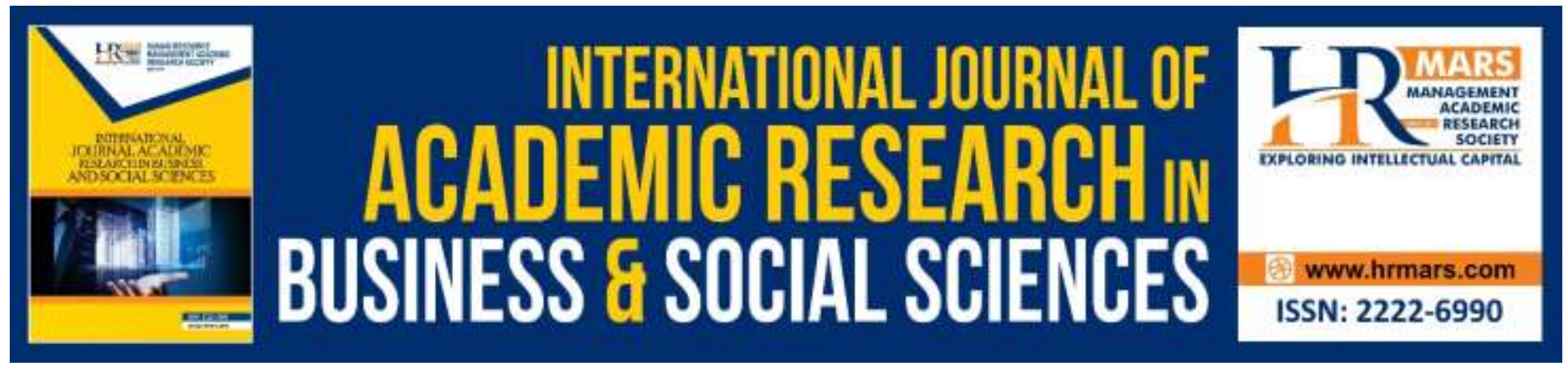

\title{
The Impact of Johor State Constitution's Promulgation in 1312 AH (1895CE)
}

Hanif Md Lateh, Izziah Suryani Arshad @ Mat Resad, Rahimah Embong

To Link this Article: http://dx.doi.org/10.6007/IJARBSS/v9-i11/6592

DOI: 10.6007/IJARBSS/v9-i11/6592

Received: 19 September 2019, Revised: 20 October 2019, Accepted: 02 November 2019

Published Online: 29 November 2019

In-Text Citation: (Lateh, Resad \& Embong, 2019)

To Cite this Article: Lateh, H. M., Resad, I. S. A. @ M., Embong, R. (2019). The Impact of Johor State Constitution's Promulgation in $1312 \mathrm{AH}$ (1895CE). International Journal of Academic Research in Business and Social Sciences, 9(11), 710-725.

\section{Copyright: (C) 2019 The Author(s)}

Published by Human Resource Management Academic Research Society (www.hrmars.com)

This article is published under the Creative Commons Attribution (CC BY 4.0) license. Anyone may reproduce, distribute, translate and create derivative works of this article (for both commercial and non-commercial purposes), subject to full attribution to the original publication and authors. The full terms of this license may be seen

at: http://creativecommons.org/licences/by/4.0/legalcode

\section{Vol. 9, No. 11, 2019, Pg. 710 - 725}

Full Terms \& Conditions of access and use can be found at http://hrmars.com/index.php/pages/detail/publication-ethics 


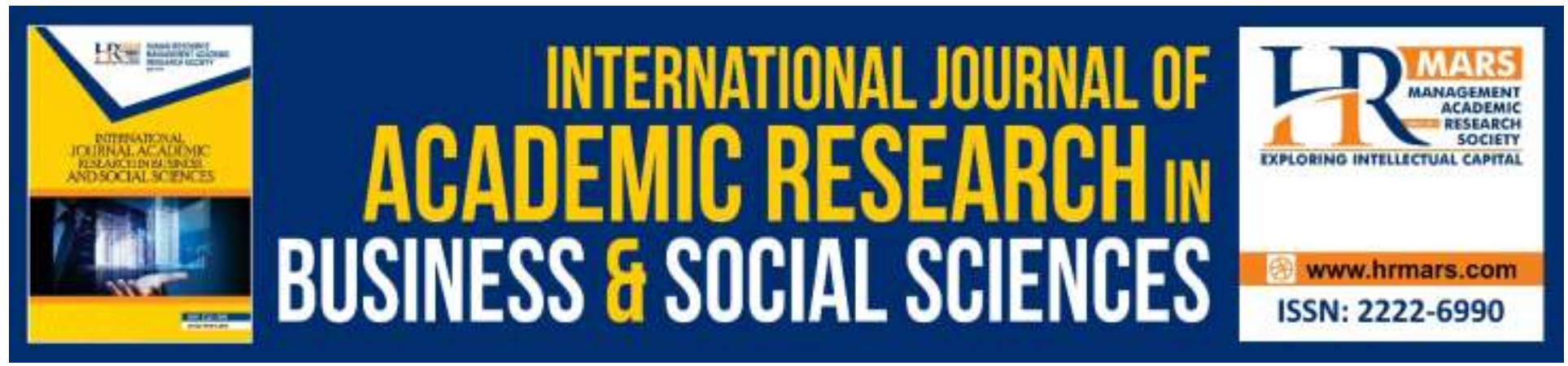

\title{
The Impact of Johor State Constitution's Promulgation in $1312 \mathrm{AH}$ (1895CE)
}

\author{
Hanif Md Lateh \\ Centre for Fundamental Studies, University of Sultan Zainal Abidin, Malaysia. \\ Izziah Suryani Arshad @ Mat Resad \\ Centre for the Middle East and Nusantara, Faculty of Islamic Studies, Universiti Kebangsaan \\ Malaysia

\section{Rahimah Embong} \\ Faculty of Islamic Contemporary Studies, University of Sultan Zainal Abidin, Malaysia.
}

\begin{abstract}
The Law of The Constitution of Johore is the first written constitution in Malaya which is introduced in 1895. This research is a qualitative one that uses content analysis approach. The original and unedited text of the Johor State Constitution is used as a primary research data, in which its contents will be analysed and correlated with historical data's of pre and post-legislation of the constitution. Based on previous research, the constitution document functions as a proof and fortification of Johor's sovereignty, thus it helps in deflecting the colonial influences over Johor. The constitution has also becoming a platform to protect the name and rank of the sultan as well as providing a legitimate family tree for the purpose of transferring inheritance and leadership of the Johor Sultanate. This constitution is created a response to the recent social situation [in Johor State and in Malaysia] and it becomes a symbol of the current Malay civilisation in the modern era. Finally, it also serves as a model for the Malaya Constitution as it is known and recognised as the first written constitution in Malaya.
\end{abstract}

Keywords: Educational Thought, Islamic Mathematics, KH. Fahmi Basya, Muslim Scholar, Holistic Education.

\section{Introduction}

The Johor State Constitution 1312 AH (1895 CE) was a constitutional law for the Johor regional government. It was drafted and promulgated during the rule of Sultan Abu Bakar (1862-1895) on 14th April 1895. It was the first officially written constitution text in Malaya. This fact has been 
approved and verified by historians and past researches. The paperwork for this topic was produced based on the text of the Johor State Constitution which includes its additional contents until 22nd April 1908. This text was copied on 10 November 2009 from the copies of the National Archive of Malaysia. 1908 was the year which the constitution was amended for the first time after it was drafted and promulgated in $1312 \mathrm{AH}$ (1895 CE) (Lateh, Resad \& Jamsari, 2018; Lateh, Resad \& Fadzil, 2016; Anukaenyi, Melody, \& Mama, 2018). The original 1895 text of the Johor State Constitution which was not amended or revised, was not found in the Malaysian National Archive, Johor branch of the National Archive, National Library of Singapore, Johor Museum and the library of the Attorney General's Chamber (AGC) Office.

The use of the 1908 version of the constitution's text which included additional contents made during that year was considered valid because prior to 1948, the constitution did not contain any major amendments, except for a few additions that did not affect the contents of the original 1895 text. Records found in the Johor State Constitution (Johor State Constitution, Reprinted, the 1895 version of the constitution incorporating all amendments up to 1st January 2008). The first amendment was made on 1st February 1948 (Undang-undang Tubuh Kerajaan Johor, 1908). Therefore, the constitution's text found in various editions prior to 1948 were valid for use and verified as the original text as the ones drafted and introduced in 1895.

According to Emerson (1970) in his book, Malaysia: A Study in Direct and Indirect Rule, he mentioned the following in regard to the Johor State Constitution:

Abu Bakar is succeeded in making Johore unique among the Malay State by the promulgation of a written constitution in April 1895. This interesting document was drawn up in both Malay and English and was drafted by a British law firm in Singapore, the Sultan's legal advisers.

Aziz (2000) made a remark on the Johor State Constitution in her book titled Pembaratan Pemerintahan Johor (1800-1945): Satu Analisis Sosiologi Sejarah:

Perlembagaan Negeri ini merupakan sebuah perlembagaan yang berasaskan perlembagaan Barat dan yang membentuk sebuah kerajaan bercorak demokrasi. Bahkan secara umum perlembagaan ini serta struktur kerajaan yang terbentuk ekoran daripada pengisytiharan perlembagaan ini adalah lebih berbentuk kebaratan. [Johor's constitution is inspired by the Western-style constitution, and the same constitution also forms a democratic government. It is worth noted that in general, the constitution, and the government structure that is formed as a result of the constitution's promulgation is actually resembling a Western governance]. 
The remark issued by Aziz was quoted by Thukiman (2011). In his own words, Thukiman remarked:

Pengenalan undang-undang ini disifatkan sebagai kemuncak pembaratan yang dilakukan oleh Johor. Pelaksanaan undang-undang ini merupakan titik tolak campur tangan British secara langsung dalam pentadbiran kerajaan Johor. Perlembagaan ini juga merupakan satu dokumen yang mengubah pemerintahan Johor dari pemerintahan raja mutlak kepada pemerintahan raja berperlembagaan dan mempunyai unsur demokratik. [The introduction of Johor State Constitution is considered as the peak of Westernisation efforts done by Johor. The legislation of this constitution is a starting point of direct British intervention in Johor's government administration. The constitution is also a document that reformed the Johor's governance from an absolute monarchy to constitutional monarchy with democratic influences].

On another note, Fawzi (1997) mentioned about the Johor-Riau influence in Johor State Constitution:

UUTKJ adalah satu dokumen persuratan perundangan yang menggabungkan kekuatan Tradisi Johor-Riau dan pengaruh perundangan moden. Dari segi persuratan ia adalah penulisan yang tinggi mutunya dengan memanisfetasikan gaya bahasa abad ke-19. Pengaruh bahasa Arab dan Melayu diadun membentuk struktur bahasanya cukup jelas waktu itu. [Johor State Constitution is a written law that combines the strength of JohorRiau traditions and the influences of modern laws. In terms of its literature quality, the constitution has manifested the use of 19th-century language style. The influences of Arabic and Malay language are combined to create a clear language structure].

All the scholars who have reviewed the Johor State Constitution was stated that the promulgation is the terrific achievement by the late of Sultan Abu Bakar. The constitution was analysed in several aspects except the topic that stressed out in this paper work based on the impacts of the legislation of Johor constitution.

\section{The Impact of Johor State Constitution}

The promulgation of Johor State Constitution has several significant impacts on the Johor state government and the Malayan federal government in general. This paperwork highlights the impacts selectively towards certain examples that can prove the relevance of the constitution's legislation during the late 19th century.

\section{Johor's Sovereignty}

Johor Sultanate was established after the fall of Malacca in 1511. From 1511 till 1699, it was known as Johor Lama. Later, the involvement of Riau region in Johor's ruling has resulted in the formation of a joint sultanate of Johor-Riau from 1699 till 1855. In 1855, the Johor Agreement 
between Temenggung Ibrahim and Sultan Ali was established in which the ruling of Johor was transferred to Temenggung Ibrahim with the exception of the Kesang-Muar area (C.O 273/17).

Referring to the sovereignty of Johor, it is generally interpreted that Johor never establish any diplomatic or political ties with any foreign power. One specific date that should be given attention as a prove of Johor's sovereignty is after East India Agreement involving both British and Dutch colonists (also known as the London Agreement) on 17th March 1824 (Emerson, R., 1970). This agreement has divided the controlled areas into British and Dutch territories. The factories in India (Dutch-owned) as well as cities and forts in Melaka was transferred to British administration. On the other side, the Dutch colonists took control of Bangkahulu (Bencoolen) and the areas in Sumatera Island. According to this agreement, Johor is regarded as a sovereign state as it is no longer tied to any of the colonial power. Researchers made such conclusion because soon after the London Agreement on 17th March 1824, a new agreement called the Johor Agreement was made on 2nd August 1824 (C.O 273/17; Said, 1941; Said, 1925; ljeoma, Ezeamama, Ebisi, 2018). The Johor Agreement contained a part which mentioned the transfer of Singapore to the British colonists. The agreement was made with Sultan Hussain who was newlyappointed in Johor-Singapore after the commencement of the London agreement. Based on this particular agreement, the researchers agreed that Johor is a sovereign government, and without the sovereignty, it would be impossible for an agreement to be made between the British colonists and the kingdom of Johor unless it was made with an approval and a permission from Sultan Abdul Rahman who was the ruler of Riau during that period.

The sovereign state of Johor was said to be established after the London Agreement of 1824. Originally, Johor was under a mandate of a sultan or king based in Riau, and the temenggung was a sultan's representative for the Johor region. After the establishment of Johor's sovereignty, there had been attempts to bring in British residents or advisers into Johor's administrations. In response, Sultan Abu Bakar and other statesmen in Johor decided to strengthen and uphold Johor's sovereignty by establishing several Westernisation efforts of the region's administration, including the promulgation of Johor State Constitution. Prior to that, the region's sovereignty had been recognised through the agreements between Johor and kingdom of Pahang. Later, an agreement with the British government in 11th December 1885 further strengthened Johor's sovereignty. The agreement stated that Johor was recognised as a nation that was not subjected to any form of colonisation and the British government recognised the sovereignty of Johor. During the same period, the British government had been a dominant force in colonising several states in Malaya. However, the agreement of 1885 made it clear that the British government did not colonise Johor and approved that the relationship between the British government and the kingdom of Johor was a cordial one (Said, 1925; J/Raja 12, Memorandum Regarding The Maharajah of Johore: His Title \& Position, National Archive of Malaysia (Johor Branch). Practically, the agreements recognised Johor's status as a sovereign nation, however it was also mentioned that: 
INTERNATIONAL JOURNAL OF ACADEMIC RESEARCH IN BUSINESS AND SOCIAL SCIENCES

Vol. 9, No. 11, November, 2019, E-ISSN: 2222-6990 @ 2019 HRMARS

The Maharajah of Johore, in the spirit of former treaties, undertakes on his part that he will not without the knowledge and consent of Her Majesty's Goverment negotiate any Treaty, or enter into any engagement with any foreign State, or interfere in the politics or administration of any native State, or make any grant or concession to other than British subject or British companies or persons of the Chinese, Malay, or other Oriental Race, or enter into any political correspondence with any foreign state (Said, 1925; Lazaridou, 2019).

The Article VI of the 1885 agreement, however, barred Johor from making any form of agreement with foreign powers. This blockade was not absolute because the Sultan of Johor was still able to do it with the consent and approval from the Queen of England or a representative of the British government in Malaya.

The existence of these agreements are evidences of Johor's sovereignty and the foreign powers such as British and Pahang government are recognising the sovereignty via these agreements. In addition to the British government and the kingdom of Pahang, other governments did recognise the sovereignty of Johor. Foreign relations between Johor and other foreign governments were established via diplomatic ties. These diplomatic ties were done via official letters and bilateral visits. Among the few official letters that symbolised these foreign relations were the ones from Johor to Pahang, Johor to Selangor, Johor to Kelantan and many more. Official bilateral visits that symbolised Johor's status as a sovereign state were the visits to Riau Kingdom, Italy, Turkey, and also visits from other nations to Johor such as from Siam (now known as Thailand), Hawaii and many more (File Extract from Around The World With a King, Visit to Johore by King Kalakava of Hawaii 1881, National Archive of Malaysia (Johor Branch). Overall, it was found that the Johor Government received its sovereignty's recognition from foreign nations. Next, the legislation of the Johor State Constitution can be interpreted as an internal evidence from Johor itself as a government with sovereignty. The Johor State Constitution is a constitutional document that serves as a proof that Johor is a sovereign state. Only a government of a sovereign nation can organise a set of rules and constitutional laws for itself. Besides, Johor is the only Malay State government that established its own constitutional laws during the $19^{\text {th }}$ century. The legislation of set of constitutional laws might not be possible in a Malay state with a British resident (federated Malay states). Johor State Constitution has emphasised on the importance of sovereignty in its introduction part by mentioning "dengan hak-hak dan kuat kuasa kerajaan kita dan kelebihan-kelebihan kita menjadi raja yang memerintah dan memiliki kerajaan Johor". The acknowledgement of ownership and governance were the two main phrase that shows the effect a Johor State Constitution has, which was acknowledging from within the kingdom that Johor is a sovereign government that is not subjected to any form of invasion or colonialism. In the constitution, there were Clauses 59 and 60 containing the agreement of 1885 which gave Johor its protection from being colonised, which was due to the status given by the British government to Johor in 1885 was considered a friendship. 


\section{Legitimacy as a Sultan or a Ruler}

The Johor State Constitution was a document that proved the legitimacy of Sultan Abu Bakar as a sultan or ruler. The change of Abu Bakar's title that started from Temenggung, then became Maharaja and later became Sultan Abu Bakar in 1885 (J/Raja 9, Letter Book of H. H. The Maharajah of Johore 1855-1868, Abu Bakar to Governor S.S, No 289- 30 Jun 1868, Approval to adopt the title of Maharajah of Johore, National Archive of Malaysia (Johor Branch). The change of title from Temenggung to Sultan has made it possible for a Sultan's title to be protected (Resad, Lateh, \& Jamsari, 2014). The protection of the title was one of the aspects mentioned in the Johor State Constitution. The doxology, introduction and the speech part of the Johor State Constitution had mentioned:

al-Wathiq bi Allah Abu Bakar bagi kerajaan dan jajahan Johor dan segala daerah takluknya sultan yang dipertuan raja dan kepala bagi darjah kerabat yang amat dihormati dan raja dan kepala bagi darjah mahkota Johor yang amat mulia.

Bahawa adalah kita dengan hak-hak dan kuat kuasa kerajaan kita dan kelebihan-kelebihan kita menjadi raja yang memerintah dan memiliki kerajaan Johor ini dan segala daerah takluknya serta pula dengan syor persekutuan dan persetujuan sekalian ahli-ahli jemaah menteri dan mesyuarat kerajaan kita dan lain-lain orang-orang besar dan ketua-ketua negeri telah menimbang memikir dan mengatakan patut harus serta munasabah dengan masa dan zaman ini akan kita dengan nama dan bagi dan kerana pihak diri kita dan bagi dan kerana pihak waris-waris ganti-ganti kita raja-raja yang memerintah atau sultansultan Johor membuat menjadi mengada dan mendirikan dan mengurnia memberi menganugerah dan menghadiahkan kepada dan bagi dan kerana pergunaan kerajaan rakyat dan isi negeri kita suatu undang-undang dan peraturan bagi memerintah dan mentadbirkan kerajaan yang dinamakan dia "Undang-undang Tubuh Kerajaan" iaitu yang akan berkekalan dan berpanjangan turun temurun menjadi dan bersifat undang-undang bagi kerajaan negeri dan rakyat kita menjadi suatu pusaka yang tiada boleh diubah dipinda ditukar diorak dipecah atau dengan sebarang jalan atau rupa perbuatan dibuka semula atau dibinasakan adanya (Undang-undang Tubuh Kerajaan Johor, 1908).

The doxology and speech parts in the constitution text proved that the Johor State Constitution had officially recorded that Abu Bakar was the royal sultan of a sovereign Johor. The phrase kerajaan kita, menjadi raja yang memerintah, and memiliki kerajaan Johor are among the important phrases that legitimise the positiion of Abu Bakar as the authority, the ruler and the king with the title of Sultan. The constitution also contained a protection of the document itself with the phrase suatu pusaka yang tidak boleh diubah dipinda diorak dipecah. This showed that the Johor State Constitution will always be the document that legitimises Sultan Abu Bakar as the governor or the king that officially rules Johor. The protection of sultan's title is retained until today. After the constitution's text went through 19 amendments, the opening speech part of the constitution is still intact to protect the title of Sultan that had been used since the rule of Sultan Abu Bakar (Undang-undang Tubuh Kerajaan Johor, 1908). 
INTERNATIONAL JOURNAL OF ACADEMIC RESEARCH IN BUSINESS AND SOCIAL SCIENCES

Vol. 9, No. 11, November, 2019, E-ISSN: 2222-6990 @ 2019 HRMARS

\section{Legitimacy of Kinship}

Johor State Constitution not only legitimised Abu Bakar as the Sultan of Johor, but it also functions as a document that legitimised the kinship of the Johor royalty. In this case, it is referring to the kinship that is eligible to rule Johor and entitled to the throne of Johor royalty, which is the kinship of Abu Bakar, Ibrahim and Abdul Rahman. The clauses that mention the legitimacy are:

Raja itu (di belakang daripada masa Raja yang ada ini) hendaklah daripada zuriat yakni keturunan daripada tubuh badan darah daging Yang Maha Mulia Sultan Yang Di Pertuan Abu Bakar Ibni Almarhum Ibrahim dan hendaklah yang demikian yang diaku sebenarnya sah dan halal dan adalah zuriat yang boleh menjadi Raja itu daripada anak cucu cicit dan sebagainya yang keturunan daripada sebelah laki-laki dahulu lepas satu keturunan lain pula hingga akhirnya yakni tiada sekali-kali boleh dan tiada sah diperajakan yang lain daripada zuriat Yang Maha Mulia Sultan [4] Abu Bakar itu selagi ada keturunannya seperti yang tersebut melainkan dikecualikan pada tentang seseorang keturunannya yang ditimbangkan dan ditentukan kemudian daripada sehabis-habis dan secukup-cukup siasat oleh "Jemaah Pangkuan Kerajaan" tiada layak dijadikan Raja iaitu yang ada kecacatan yang besar-besar dan berat-berat yang menyalahi sifat Raja-raja seperti gila dan buta dan bisu atau mempunyai sifat-sifat yang kejian yang tiada dibenarkan oleh hukum syariat menjadi Raja.

Jikalau pada sesuatu masa telah habis dan tiada lagi tinggal keturunan zuriat Yang Maha Mulia Sultan Abu Bakar atau jikalau adapun tiada layak diperajakan oleh kerana sebabsebab yang tersebut dalam fasal yang ketiga di atas itu hendaklah dipilih dan dilantik dijadikan Raja seseorang anak Raja laki-laki daripada keturunan zuriat Almarhum Temenggung Ibrahim maka jikalau tiada pula atau tiada yang ditimbangkan layak daripada keturunan zuriat Almarhum Ibrahim itu hendaklah dipilih dan dilantik dijadikan Raja seseorang laki-laki daripada keturunan zuriat Almarhum Temenggung Abdul Rahman dan salah satu daripada hal ini hendaklah yang dijadikan Raja itu yang sebenarnya daripada darah yang diaku sah dan halal (Clause 3-4, Undang-undang Tubuh Kerajaan Johor, 1908).

The two clauses in the constitution had stated in clear detail that the royal throne kinship system would be transferred to the son of Sultan Abu Bakar. The absence of an eligible heir or inability for an eligible heir to fulfil the requirements would result in the consideration of choosing an heir from the Temenggung Daing Ibrahim blood line (Tang, 2007). Otherwise, if it is not possible to find an eligible heir from Daing Ibrahim blood line or the heir cannot fulfil the requirements of being a Sultan, the kingdom would consider finding an eligible heir from the Temenggung Abdul Rahman blood line. Through the legislation and promulgation of Johor State Constitution, the descendants of Sultan Abu Bakar, Temenggung Ibrahim and Temenggung Abdul Rahman were recognised as the eligible heir of Johor royalty throne. The existence of these clauses immediately barred the descendants of Sultan Hussain from making any claims to the throne of Johor royalty as the Johor State Constitution already had made descendants of Abu 
Bakar, Ibrahim and Abdul Rahman as the only recognised heir, despite the fact that initially, the descendants of Sultan Hussain were the ones who would have been elected to take over the throne. The legitimisation of kinship is still up hold and retained in the latest text of the Johor State Constitution. The latest document still contains the same rules but they have been unified in Clauses 3(1), 3(2) and 3(3). The Temenggung was in fact a part of the royal family (Clause 3, Undang-undang Tubuh Kerajaan Johor, 1908). The legislation of Johor State Constitution has made the descendants of Sultan Abu Bakar as the current rulers of Johor till this day:

Sultan Abu Bakar

1862-1895

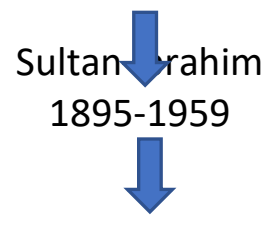

Sultan Ismail

1959-1981

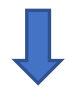

Sultan Iskandar

1981-2010

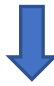

Sultan Ibrahim

2010-kini

Figure 1 The Rulers of Modern Johor 1862-2015

Source: Resad et al., 2014.

\section{Protection against Colonialisation}

The contents of Johor State Constitution generally focus on the administration system of Johor, but at the same time, there are also mentions of protecting the sovereignty of Johor from any form of colonialization. The $19^{\text {th }}$ century saw the British expanding their influences on Malaya. In fact, the British government has targeted Johor as its latest territory since the 1880s. The efforts of the British forces to plant British agents into Johor's administration was done in three attempts: the sanctions against Johor Advisory Board, the construction of railway tracks through the areas of Johor and forcing Dato' Seri Amar Diraja to resign (Basri \& Haron, 1978). These attempts were done after the promulgation of the Johor State Constitution as the British understood that it was impossible for them to openly spread its colonial influences in Johor like what they did in Perak, Pahang and other states. Based on the past experiences, the Weld efforts and incidents in several Malay states in Malaya, the constitution has decided that: 
Raja itu tiada sekali-kali boleh menyerahkan atau berbuat sebarang perjanjian atau ikhtiar hendak menyerahkan akan negeri atau sesuatu bahagian daripada negeri dan kerajaan Johor itu kepada sebarang kerajaan atau kuasa bangsa Eropah atau sebarang lain kerajaan atau bangsa sama ada oleh kerana pada fikirannya susah atau keberatan padanya menjadi Raja atau oleh kerana tiada suka dia memerintah atau oleh kerana hendak mendapat mengambil dan menerima sebarang bayaran atau pencen daripada bangsa atau kerajaan lain dan demikian juga ada larangan dan tegahan ini terletak dan terhukum diatas segala dan tiap-tiap seorang daripada waris dan kerabat Raja.

Maka jikalau dilalui atau dicuba lalui larangan dan tegahan ini jika Raja sendiri disifatkanlah dia berdosa memecahkan amanah yang diletakkan Tuhan atasnya dan demikian tiada diwajibkan rakyat negeri melanjutkan setia lagi padanya dan jika kerabat Raja derhaka ia kepada Raja dan kerajaan dan demikian bolehlah dihukumkan dengan sebarang hukuman yang ditimbangkan patut.

Menteri-menteri dan jemaah pengakuan kerajaan tiada juga boleh sekali-kali berikhtiar atau berbuat sebarang perjanjian dengan sebarang kuasa atau kerajaan Eropah atau lainnya dengan maksud hendak menyerahkan negeri dan kerajaan Johor. Maka jikalau dilanggar atau dicubanya hendak melanggar akan larangan dan tegahan ini terjatuhlah ia pada hukuman orang yang derhaka kepada Raja dan kerajaan dan bolehlah dihukumkan sekalian yang berdosa itu dengan hukuman yang berpadan dengan dosanya (Clause 15-16, Undang-undang Tubuh Kerajaan Johor, 1908).

Both clauses have stated in clear and concise detail, the sanctions that have been placed on the king or ministers to prevent them from doing an agreement to surrender Johor to any foreign or European powers. The phrase pihak ketiga (third party) mentioned clearly in the constitution are referring to the European governments or European powers. As we know, the major European power who is actively colonising Malaya via formal agreements is the British government. Implicitly, the focus of these particular clauses in the constitution is to stop the British government from taking over Johor. Both clauses are aiming in stopping the ongoing colonisation of Malaya by the British government during that period of time. 19 years after the Johor State Constitution was promulgated, Johor finally and formally received its first British resident in its government. Johor was last Malay state in Malaya that managed to keep British residents or agents out of the state's administration, in the time when most of Malaya was finally taken over by the British or Siam government in 1914, with the exception of Terengganu (Basri \& Haron, 1978; Zakaria, 2009). Turnbull (2009) also made a similar remark:

Abu Bakar bequeathed a new type of state, with defined territorial frontiers, a written constitution, and a bureaucracy modernised to a degree on western lines, but both he in his successor aimed to keep the British Agent for which the 1885 treaty made provision.

These clauses in the Johor State Constitution were among the steps taken by Sultan Abu Bakar to strengthen Johor's sovereignty and most important, to ward off any attempts of 
colonisation by the British government and other foreign powers that were targeting Malaya during that time.

\section{Islam and Freedom of other Religion Practitioners}

The Johor State Constitution included the importance of Islam in Johor. Islam was alleviated to the highest position as the state religion of Johor. Besides Islam being declared an official religion of Johor, the constitution also highlighted the importance of having a person with Islamic faith and thorough understanding of the religion as the ruler of Johor in order to preserve and take care of religion. This can be seen in the pre-requisites of electing a king and a minister (Clause 2 and 30, (Undang-undang Tubuh Kerajaan Johor, 1908). Clause 57 of the constitution mentioned the status of Islam as the official religion of Johor:

Adalah yang dikatakan 'igama Islam' bagi jajahan dan kerajaan Johor ini iaitu igama Islam maka yang demikian hendaklah igama Islam itu berpanjangan dan berkekalan selamalamanya menjadi dan diaku dan disebut 'igama negeri' yakni tiadalah sekali-kali boleh sebarang igama lain dijadikan atau disebut igama negeri sungguhpun segala igama lain ada dibenarkan dan sentiasa termaklum patut dibenarkan dengan aman dan sempurna boleh diperigamakan dalam segala dan segenap daerah takluk kerajaan Johor oleh orangorang yang berigama akan dia (Clause 57, (Undang-undang Tubuh Kerajaan Johor, 1908).

The clause highlighted the status of Islam as the sole official religion of Johor that shall not be questioned or challenged by any party. The importance of Islam as a religion in Johor began long time ago during the years after the downfall of Melaka Sultanate and before the kingdom of Johor was established. Islam is still widely practised hundreds of years after the fall of Melaka and spread throughout Malaya. Believers of other religions in Johor were guaranteed equal rights to practise their faiths and this proved the concept of religious freedom and the plurality and harmony of religions in Johor during that period of time. Immigration data of 1863 showed the number of Chinese immigrants were around 49,600, while Indian immigrants were around 12,800 . The number of Chinese immigrants showed an increase of $10 \%$ during the period of 38 years (Thukiman, 2011). The clause was later copied and inserted into Terengganu State Constitution of 1911 and researchers believed that the same clause were also brought into the Federal Constitution of Malaysia of 1963. See clause 51, Terengganu State Constitution 1911. See the comparison between Johor and Terengganu State Constitution (Fawzi, 1999).

\section{An official and Written Administration Structure}

One of the aims of creating a constitution is developing a written administration structure. It is related to the term 'constitutional mechanism' said by Chancal (2015). The administration arrangements of the Johor's administration were different to the ones from other Malay states in Malaya. Referring to the Johor State Constitution, the basic structure of Johor Government can be tabled and visualised as the following diagram: 


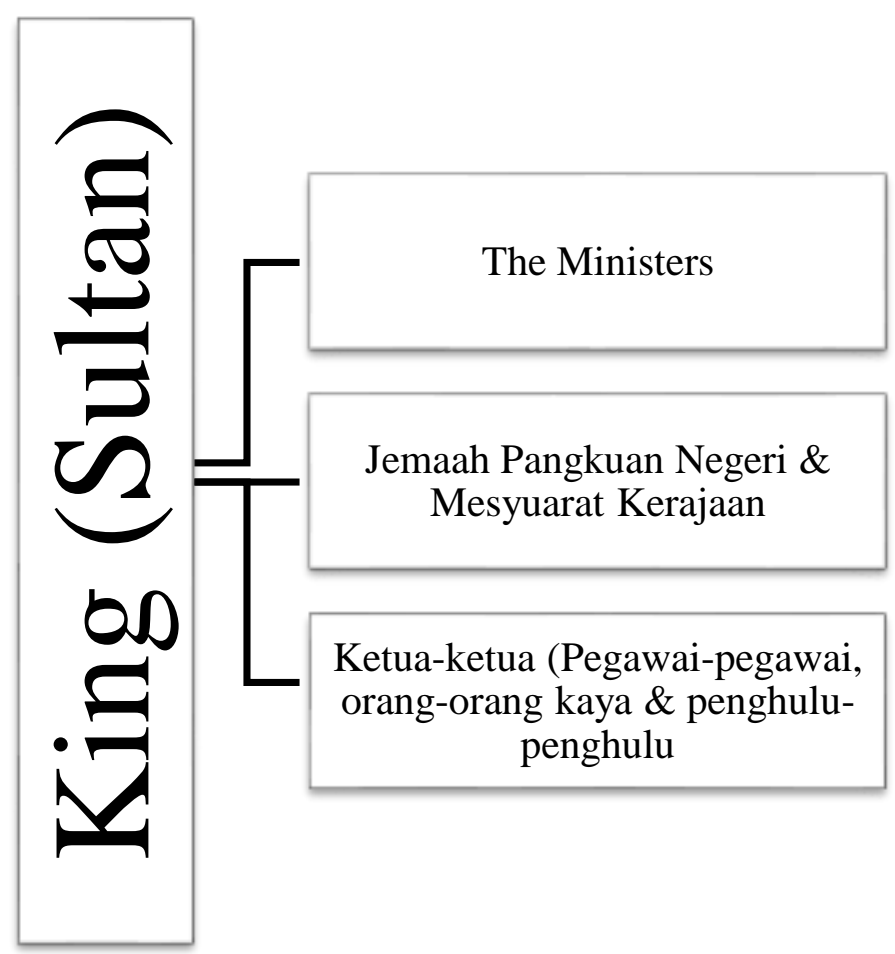

Figure 2 Administration structure of Johor

Based on the diagram, it can be understood that the Johor Government is divided into the following authorities:

a. The Ministers: Responsible in the management of state administration. Act as sultan's advisers and hold portfolios in government administration.

b. Jemaah Pangkuan Negeri: Responsible in determining the appointment of a king, heir, Crown Prince and matters related to the Crown Throne. "Jemaah Pangkuan Negeri" are elected by the cabinet ministers and leaders in the mentioned diagram.

c. Executive Council: Responsible in drafting and legislating laws Established by several ministers and leaders chosen from suggestions of the cabinet and appointed by the current ruler.

The similar structure is also found on several Malay kingdoms which are known as orang besar berempat, berlapan and many other authorities. However, the other Malay kingdoms do not have written administration structures which would result in the practice of the managing government are prone to changes from time to time. Through the promulgation of the Johor State Constitution, Johor was able to stay ahead of other Malay states by owning and having a well-defined administration structure. This structure can be seen in the constitution clauses 28 and 45, which meant that the structure can be modified, but it cannot be done easily due to existence of sanctions against appointment, impeachment and many more. Prior to the 
constitution, the structure of government can be identified via documents in historical writings. There was no specifically-written document that was meant to explain and verify the structure of government like the ones within the Johor State Constitution.

\section{A Symbol of Malay Civilisation}

Documents of a state's constitution is a highly valued one in the aspect of nationhood. In the case of Johor State Constitution, the sources that helped developed the constitution came from various sources (Lateh \& Resad, 2015). These various sources were blended and adapted with socio-political conditions of the Malay community during the $19^{\text {th }}$ century. The Malay society and kingdom have gone through a long phase starting from the establishment Hukum Kanun Melaka, Hukum Kanun Pahang and many more. However, when it came to management or the written system of governance in the form of constitution that should become an integrated aspect of law legislations, the Malay society and kingdom seemed left behind in this matter. But, the existence of such system prior to the establishment of Johor State Constitution were not denied and they were in fact have been acknowledged.

The Statute of Johor has been established from the blend of various resources and later it was put through several years of management practise of the ancient Malay kingdoms that have been inherited by Johor. These experiences were later made as references for the drafting and legislation of a constitutional document that was announced in year $1312 \mathrm{AH}$ or $1895 \mathrm{CE}$. The Johor Government has gone through several experiences related to management of its own government, beginning from the Melaka Kingdom, Old Johor Kingdom, Johor-Riau Kingdom and later Modern Johor Kingdom. Surely the Johor State Constitution was a reflection of a matured administration management system that is a result of 4 centuries of experiences. Therefore, the Johor State Constitution also served as a benchmark of government management system for the Malay civilisation. In terms of the constitution's content, it can be summarised into the following points:

a. The shift of the king's function and roles: In ancient and pre-Islamic Malay community, a king was considered a god or the shadow of God on earth (Fadzil, 1999). The shift, however, occurred in the understanding of how a king should function and a king's duty. The understanding of a king's function and duty finally led to the concept of real loyalty. This was the important function that had been implemented in the constitution, adapting a Hinduism-influenced understanding of a king and transforming into an Islam-influenced understanding. Later, the constitution clarified the true understanding towards the royal institutions.

b. The shift from absolute monarchy to constitutional monarchy: The constitution had introduced several clauses to block a king's power from becoming absolute.

c. The concept of meeting: The concept of discussing and developing a consensus was implemented in the constitution. This helped the Malay community to get rid of individualistic, biased and one-sided argument traits. 
d. Social justice principles: The principle emphasised on the freedom of speech, religious rights, the right to practice traditional customs and many other implementations made by the constitution.

\section{A Model of Constitution in Malaya}

The Johor State Constitution became a model constitution for all other state constitutions in Malaya. The comparisons made by Fawzi (1999) between Johor State Constitution and Terengganu State Constitution had discovered several obvious similarities. The same thing was also observed when the Johor State Constitution was compared to the Kedah State Constitution that was introduced in $1^{\text {st }}$ February 1948 (Resad et al, 2014). Besides, it is worth noted that the Federal Agreement of 1948 also had similarities with Johor State Constitution (See the analysis of 1948 Federal Agreement in, Adam (1999).

\section{Conclusion}

The promulgation of Johor State Constitution in 1312 AH (1895 CE) was suitable with the socio-political climate of Johor during that period of time. The constitution had a great impact on the field of politics as it was able to influence the royal institution, administration and governance in Johor. Besides, the constitution had left an impact on British's colonialization policies and efforts and at the same time, it served as a guidance for the modern Malay civilisations and had a great effect on the other Malay states in Malaya.

The Johor State Constitution is celebrating its $120^{\text {th }}$ anniversary and it is still used as the law documents that have become the core of the Johor State Government. This shows that the constitution is a highly valuable document that becomes a guideline for the political developments in Johor and also preserved and well-kept until today. Although there are amendments, additions and omissions of several clauses, the significance of the document in providing guidance for the administration of government is still relevant till this day. The importance of Islam and Malay identity as a core for political development in Johor is also mentioned in the constitution.

\section{Acknowledgement}

This research received funding from the Universiti Sultan Zainal Abidin, Terengganu, Malaysia by the research grant Penilaian Fakta Dalam Silibus Sejarah Malaysia Peringkat Sijil Tinggi Pelajaran Malaysia (UniSZA/2018/GOT/04 R0053). We are also indebted to everybody who contributed in the research and the writing of this paper.

\section{Corresponding Author}

Rahimah Embong, Ph.D, is Associate Professor at Department of Education, Dakwah \& Islamic Civilization, Faculty of Islamic Contemporary Studies, Universiti Sultan Zainal Abidin (UniSZA), Kampus Gong Badak, 21300 Kuala Nerus. Terengganu, Malaysia.

Email: rahimahembong@unisza.edu.my 


\section{References}

Adam, R. (1999). Warisan ketatanegaraan Melayu dalam Perjanjian Persekutuan 1948: Dengan rujukan khas kepada pentadbiran negeri Melayu [Malay constitutional heritage in the 1948 federal agreement: With special reference to Malay States Administration]. Warisan Persuratan Johor II [Johor Literary Heritage II] (pp. 419-442). Johor Bahru: Yayasan Warisan Johor.

Anukaenyi, B., Melody, M., \& Mama, L. E. (2018). Fundamental Problems Faced by the Management of Private Secondary Schools in Enugu Metropolis. International Journal of Academic Research in Progressive Education and Development, 7(4), 267-279

Aziz, R. A. (2000). Pembaratan Pemerintahan Johor (1800-1945): Satu Analisis Sosiologi Sejarah [Westernisation Johor Kingdom 1800-1945: An Analysis of Historical Sociology]. Kuala Lumpur: Dewan Bahasa dan Pustaka.

Basri, F. \& Haron, H. (1978). Sejarah Johor Moden 1855-1940 [History of Modern Johor 18551940]. Kuala Lumpur: Muzium Negara.

C.O 273/17. (1862). Colonial Office: Straits Settlements Original Correspondence. Secretary of State. Treaty Johore and Pahang, 17 June 1862 (Unpublished document). Bangi: National University of Malaysia, Library Archive.

Chanchal, K. S. (2015). Reimagining federalism in India: Exploring the frontiers of collaborative federal architecture. Asia-Pacific Social Science Review, 15(1) 2015, pp. 1-25. Retrieved from http://apssr.com/wp-content/uploads/2018/03/1_sharma-061615.pdf

Emerson, R. (1970). Malaysia: A Study in Direct and Indirect Rule. Kuala Lumpur: University of Malaya Press.

Fadzil, S. (1999). Pemikiran politik Melayu: Menilai Itqanu I-Muluk Warisan Persuratan Johor II [Johor Literary Heritage II] (pp. 309-316). Johor Bahru: Yayasan Warisan Johor.

Fawzi, A. (1997). Undang-undang Tubuh Kerajaan Johor 1312 (1895): Kepentingan dari segi persuratan dan sejarah. Warisan Persuratan Johor [Johor Literary Heritage] (pp. 169-180). Johor Bahru: Yayasan Warisan Johor.

Fawzi, A. (1999). Undang-undang Tubuh Kerajaan Johor Tahun 1895: Suatu pemerhatian terhadap aspek ketatanegaraan dan persuratan [The Law of The Constitiution $\mathrm{f} \mathrm{Johore} 1312$ (1895): The importance of literature and history]. Warisan Persuratan Johor II [Johor Literary Heritage II] (pp. 383-410). Johor Bahru: Yayasan Warisan Johor.

File National Archive of Johor. (1881). Extract from Around the World with a King, Visit to Johore by King Kalakava of Hawaii 1881 (Unpublished document). Johor: National Archive of Malaysia, Johor Branch.

Ijeoma, M. M., Ezeamama, M., Ebisi, L. N. E. (2018). Economic Policy Management in Nigeria: Effective Diversification Approaches, International Journal of Academic Research in Accounting, Finance and Management Sciences 8 (4): 195-203.

J/Raja 12. (1868). Memorandum Regarding the Maharajah of Johore: His Title \& Position (Unpublished document). Johor: National Archive of Malaysia, Johor Branch. 
INTERNATIONAL JOURNAL OF ACADEMIC RESEARCH IN BUSINESS AND SOCIAL SCIENCES

Vol. 9, No. 11, November, 2019, E-ISSN: 2222-6990 @ 2019 HRMARS

J/Raja 9. (1868). Letter Book of H. H. The Maharajah of Johore 1855-1868, Abu Bakar to Governor S.S, No 289- 30 Jun 1868, Approval to adopt the title of Maharajah of Johore (Unpublished document). Johor: National Archive of Malaysia, Johor Branch.

Lazaridou, I. (2019). Travelling around the world through the fairy tales. A project of developing communication skills and multicultural awareness in kindergarten. Multilingual Academic Journal of Education and Social Sciences, 7(1), 62-70. (in Greek)

Lateh, H. M, Resad, I. S. M \& Fadzil, A. F. M. (2016). Penilaian Kanun I Esasi sebagai sumber pembentukan perlembagaan Johor [The Assessment of Kanun I Esasi 1876 as the source for the formation of the Johore Constitution 1895]. Islamiyyat, 38(2), 117-131. doi: 10.17576/islamiyyat-2016-3802-02

Lateh, H. M., Resad, I. S. M., \& Jamsari, E. A. (2018). Analysis of Loanwords in Text of Johore State Constitution 1312h (1895). International Journal of Civil Engineering and Technology, 9(1), 763-770. Retrieved from http://www.iaeme.com/IJCIET/issues.asp?JType=IJCIET\&VType=9\&IType=1

Resad, I. S. M., Lateh, H. M., \& Jamsari, E. A. (2014). Sumbangan Undang-undang Tubuh Kerajaan Johor 1312(1895) terhadap politik Johor [Contribution The Law of the constitution of Johor 1312(1895) on Johor political]. Islam dan Ketamadunan Melayu [Islam and Malay Civilization] (pp. 109-118). Kuala Lumpur: Akademi Pengajian Islam, Universiti Malaya.

Resad, I. S. M., Lateh, H. M., \& Kadiron, H. M. (2015). Pengaruh Islam dalam Undang-undang Tubuh Kerajaan Kedah [Islamic influence in The Law of the constitution of Kedah]. Jurnal Melayu, 14(1), 32-47. Retrieved from http://ejournal.ukm.my/jmelayu/article/view/9570

Said, M. (1925). Treaties and Agreements Affecting the State and Territory of Johore. Johore: The Government Printing Office Johore.

Said, M. (1941). Buku Teriti Johor dengan Pertambahannya [Book of Johor treaties with intercalation]. Johor Bahru: Lembaga Malaya Press.

Sinclair, K. (1967). Hobson and Lenin in Johore: Colonial Office Policy towards British Concessionaires and Investors 1878-1907. Modern Asian Studies, 1(4): 335-351.

Tang, R. (2007). Interpreting Abu Bakar, the ruler of Johor (1862-1895): The reconstruction of selected issues (Unpublished doctoral dissertation). School of African and Oriental Studies, University of London.

The Law of The Constitution of Johor 1895. (2008). Putrajaya: Office of the Attorney General, Malaysia.

Thukiman, K. (2011). Sejarah Johor dalam Pelbagai Perspektif [Johor History in various perspective]. Johor Bahru: Penerbit UTM Press.

Turnbull, C.M. (2009). British colonialism and the making of the Johor monarchy. Indonesia and the Malay World, 37(109): 227-248.

Undang-undang Tubuh Kerajaan Johor 1312 (1895). (1908). Johor: National Archive, Malaysia.

Zakaria, A. (2009). Politik Melayu sebelum dan selepas penjajahan British [Malay politics pre and post British colonization]. Peradaban Arab-Islam dan Masyarakat Melayu [Arab-Islamic Civilization and Malay Society] (pp. 297-330). Bangi: Jabatan Pengajian Arab dan Tamadun Islam, UKM. 